\title{
SCALING-UP AN INTEGRATED CARE FOR PATIENTS WITH NON-COMMUNICABLE DISEASES: AN ANALYSIS OF HEALTHCARE BARRIERS AND FACILITATORS IN SLOVENIA AND BELGIUM
} NADGRADNJA CELOSTNE OSKRBE PACIENTOV S KRONIČNIMI NENALEZLJIVIMI
BOLEZNIMI: ANALIZA SPODBUJEVALCEV IN OVIR V SLOVENIJI IN BELGIJI

\author{
Črt ZAVRNIK ${ }^{*}$, Katrien DANHIEUX², Miriam HURTADO MONARRES ${ }^{1}$, Nataša STOJNIĆ ${ }^{1}$, \\ Majda MORI LUKANČIČ́1, Monika MARTENS ${ }^{2,3}$, Zalika KLEMENC-KETIŠ1,4,5, \\ Edwin WOUTERS ${ }^{2}$, Josefien van OLMEN ${ }^{2,3}$, Antonija POPLAS-SUSIČ ${ }^{1,4}$
}

\author{
${ }^{1}$ Community Health Centre Ljubljana, Primary Healthcare Research and Development Institute, \\ Metelkova 9, 1000 Ljubljana, Slovenia \\ ${ }^{2}$ Institute of Tropical Medicine Antwerp, Belgium \\ University of Antwerp, Belgium \\ ${ }^{4}$ University of Ljubljana, Faculty of Medicine, Department of Family Medicine, Poljanski nasip 58, 1000 Ljubljana, Slovenia \\ ${ }^{5}$ University of Maribor, Faculty of Medicine, Department of Family Medicine, Taborska 8, 2000 Maribor, Slovenia
}

\section{IZVLEČEK}

Ključne besede: nadgradnja, kronične nenalezljive bolezni, na pacienta usmerjen oskrba, primarno zdravstveno varstvo, celostna oskrba

\begin{abstract}
Keywords:

scale-up, noncommunicable diseases, patientcentered care, primary healthcare, integrated healthcare

Introduction: Although the concept of integrated care for non-communicable diseases was introduced at the primary level to move from disease-centered to patient-centered care, it has only been partially implemented in European countries. The aim of this study was to identify and compare identified facilitators and barriers to scale-up this concept between Slovenia and Belgium.

Methods: This was a qualitative study. Fifteen focus groups and fifty-one semi-structured interviews were conducted with stakeholders at the micro, meso and macro levels. In addition, data from two previously published studies were used for the analysis. Data collection and analysis was initially conducted at country level. Finally, the data was evaluated by a cross-country team to assess similarities and differences between countries.

Results: Four topics were identified in the study: patient-centered care, teamwork, coordination of care and task delegation. Despite the different contexts, true teamwork and patient-centered care are limited in both countries by hierarchies and a very heavily skewed medical approach. The organization of primary healthcare in Slovenia probably facilitates the coordination of care, which is not the case in Belgium. The financing and organization of primary practices in Belgium was identified as a barrier to the implementation of task delegation between health professionals.
\end{abstract}

Conclusions: This study allowed formulating some important concepts for future healthcare for non-communicable diseases at the level of primary healthcare. The results could provide useful insights for other countries with similar health systems.

Uvod: Celostna oskrba kroničnih nenalezljivih bolezni je koncept, ki v bolezen usmerjeno oskrbo nadomešča z oskrbo, usmerjeno na pacienta. Kljub obstoju učinkovitega modela takšne obravnave pa je bil slednji v evropskih državah doslej uveden le delno. Namen te študije je prepoznati in primerjati spodbujevalce in ovire za nadgradnjo celostne oskrbe $v$ Sloveniji in Belgiji.

Metode: $V$ sklopu te kvalitativne študije je bilo izvedenih 15 fokusnih skupin in 51 intervjujev z odločevalci na mikro-, mezo- in makroravni. Poleg tega so bili $v$ analizo vključeni tudi podatki iz dveh predhodno objavljenih študij. Zbiranje podatkov in analiza sta bila sprva izvedena v vsaki državi ločeno, nato pa je mednarodna ekipa raziskovalcev primerjala podatke ter opredelila razlike in podobnosti med državama.

Rezultati: $V$ raziskavi so bile izpostavljene štiri teme: na pacienta usmerjena oskrba, timsko delo, koordinacija oskrbe ter prenos zadolžitev med zdravstvenimi delavci. Odločevalci obeh držav so izpostavili, da vzpostavljena močna hierarhija in strog medicinski pristop $k$ obravnavi pacientov $s$ kronično boleznijo predstavlja bistveno oviro za uresničitev resničnega timskega dela in na pacienta usmerjene oskrbe. V nasprotju z Belgijo organizacija primarnega zdravstvenega varstva $v$ Sloveniji najverjetneje spodbuja koordinacijo oskrbe. V Belgiji pa sta bila kot bistvena ovira za prenos zadolžitev med zdravstvenimi delavci izpostavljena način financiranja in organizacija primarnih ambulant.

Zaključki: Ta študija predstavlja nekaj za prihodnost pomembnih načel obravnave kroničnih nenalezljivih bolezni na primarni zdravstveni ravni. Rezultati lahko predstavljajo uporabna spoznanja za druge države s podobnim zdravstvenim sistemom.

This article was presented at the ISCPC conference, which took place virtually on the 12th of February, 2021. The conference was organised by the Community Health Centre Ljubljana and Medical Faculty, University of Ljubljana, Slovenia.

${ }^{*}$ Corresponding author: E-mail: crt.zavrnik@zd-lj.si 


\section{INTRODUCTION}

Non-communicable diseases (NCDs) increasingly represent a major public health problem worldwide as a result of ageing populations and the global diffusion of unhealthy lifestyles $(1,2)$. The concept of integrated care has been introduced in recent years to surpass fragmented, diseasecentered care with patient-centered care. An effective model of an integrated care package with interventions for chronic diseases is endorsed by the World Health Organization (WHO) and includes the following elements: (a) identification; (b) primary healthcare (PHC) treatment; (c) health education; (d) self-management support; and (e) cooperation between caregivers (3).

Although many European countries have partially implemented the above-mentioned model in PHC, barriers still exists at various (patient/provider, healthcare organization and policy) levels (4). Knowledge is therefore needed about what hinders and promotes the integration of the integrated care package at these levels. Furthermore, different types of healthcare system exist across Europe and may lead to different barriers and facilitators, but their relationship is not well known (5). Recently published studies also show that facilitators and barriers to integrated care depend mainly on the macro-level context of the country (cultural inertia, type of health system, laws and regulations) (6). However, some universal barriers have been identified in European countries: fragmented care by different specialists from different levels of care, lack of guidelines and education/ training for treating patients with multiple NCDs, focus on a single NCD, focus on exclusively somatic health, and neglect of mental health. Implementation and increased use of care coordinators for more complex patients and improvement of information and communication technology were identified as facilitators $(6,7)$.

For this paper, the healthcare systems from two European countries, Slovenia and Belgium, were selected for evaluation of their implementation of barriers and facilitators of integrated care for non-communicable diseases management. Although both are classified as high-income countries, there are significant differences in healthcare systems and broader contexts, relating to the amount of resources, the healthcare provider payment system and organization.

Slovenia is a post-socialist republic with a population of 2.1 million inhabitants and annual health expenditure of 2961 international dollars (8.2\% of gross domestic product, GDP) per capita in $2017(8,9)$. The health system is centralized with compulsory social insurance; care is provided mainly through public health centers, although private provision of health services is also possible. The capitation system is established at the primary level and a strong gatekeeping role is performed by general practitioners (GPs) (10). In
2011, registered nurses were introduced into GP practices to screen for NCDs and manage patients with stable NCDs $(11,12)$. Community nurses are responsible for nurse care at patients' homes.

Belgium is a federal country with a population of 11.5 million inhabitants and annual health expenditure of 5119 international dollars (10.3\% of GDP) per capita in 2017 (8, 9). The health system is decentralized and privatized, but regulated. Healthcare is based on the free choice of physician and mainly on the fee-for-service payment. Primary care practices are independent and differ in many aspects, such as size and support of administrative personnel. Most practices only consist of GPs (a solo or group practice), few have dieticians or nurses (13).

This paper uses qualitative data on integrated care package implementation in two countries to (1) assess the barriers and facilitators to scale-up at patient and organizational level and (2) compare identified facilitators and barriers between the two countries.

\section{METHODS}

This research is part of the ongoing project SCUBY (SCaleUp diaBetes and hYpertension care) - an international project that identifies the opportunities and barriers and implements the pathways to scale-up the integrated care package for patients with hypertension and type 2 diabetes in three different countries: Cambodia, Slovenia and Belgium (14). This sub-study contains only data from the two high-income countries involved, Slovenia and Belgium.

\subsection{Design and sampling}

In order to get a comprehensive overview of the Slovenian and Belgian health system, a multi-level qualitative framework was used, based on WHO-definition: patients and health professionals as the micro level, community and health organizations as the meso level and the national level (regulatory, financial, professional and scientific stakeholders) as the macro level (15). At the micro level, inclusion criteria for patients with T2D or HTN were age 65 years or older and ability to communicate verbally; for health professionals, inclusion criteria were representation of different geographic locations and coverage of all primary care team members. At the meso and macro levels, participants were purposively selected on the basis of their relevance to the themes, role in the health system, availability and the coverage of all levels. A qualitative study was then conducted among these participants using focus groups and semi-structured interviews. As data collection progressed, additional relevant key informants were identified using the snowballing technique and subsequently added to the list until saturation was reached. In addition, data from previously published studies were used for analysis $(16,17)$. 


\subsection{Data collection}

The primary data were collected through individual, indepth, semi-structured interviews and focus groups. Prior to this, both research teams developed a common thematic interview guide for data collection based on potential opportunities and barriers, relying on both literature research and contextual knowledge. The main themes were: identification, treatment in primary care, health education, self-management and cooperation between healthcare providers. All interviews and focus groups were conducted in person by an experienced researcher and an observer who made notes about nonverbal communication. They took place at the predefined location in a room equipped for the audio-video recording. They lasted 50-90 minutes and were audio recorded after written informed consent was obtained. Data were collected until data saturation on the research topic was reached for each level (iterative approach).

In Slovenia, 15 focus groups (micro level) and 23 interviews (meso and macro level) were conducted between May 2019 and April 2020. In Belgium, 28 interviews with key informants at meso and macro level were conducted between April 2019 and September 2020; additionally, micro-level data were supplemented with quotes from two previously published studies, written by three authors also involved in the current study, as this data are applicable to the context of our research - focus groups about opportunities and barriers of the healthcare system for patients with chronic diseases, and semi-structured interviews about views of GPs, nurses and chronic disease patients on inter-professional cooperation between GP and nurse $(16,17)$. Meetings and exchanges were held with the research groups of both studies, to understand the context and the methods used, and to discuss the relevance and validity of these data for the research questions in this study. New policy measures have been planned, but are not implemented yet in Belgium. Table 1 outlines the details of the data collection characteristics.

Table 1. Data collection characteristics.

\begin{tabular}{lll}
\hline $\begin{array}{l}\text { Participants } \\
\text { level }\end{array}$ & Slovenia & Belgium \\
\hline Micro & $\begin{array}{l}15 \text { focus groups: seven } \\
\text { with patients } \\
1 \text { rural), eight with } \\
\text { health workers } \\
\text { urban, } 3 \text { rural) }\end{array}$ & $\begin{array}{l}\text { Secondary data, } \\
\text { based on two recently } \\
\text { published relevant } \\
\text { studies (16,17) }\end{array}$ \\
Meso & 11 interviews & 15 interviews \\
Macro & 12 interviews & 13 interviews \\
\hline
\end{tabular}

1 - Patients with hypertension and/or type 2 diabetes.

2 - General practitioners, registered nurses, practice

nurses and community nurses.

\subsection{Data analysis}

\subsubsection{Primary data analysis}

The interviews and focus groups were transcribed verbatim. The analysis was carried out with the QSR NVivo software, including data from two previously published Belgian studies $(16,17)$. A bottom-up (inductive) approach was used. This resulted in a common code tree which was adopted by both research teams. During the analysis the themes were refined (deductive approach). In each country separately, the analysis of each interview or focus group was carried out by two independent researchers (ČZ, NS, MC, MML, KD, MM, JVO); then the discussion was organized with the supervisors. This qualitative thematic data analysis resulted in two separate codebooks (one for each country).

\subsubsection{Secondary data analysis}

During the secondary analysis, the authors of this study (ČZ, KD, MM and senior researchers APS, JVO and EW) used triangulation to compare the codebooks of both countries and to assess similarities and differences between the two countries in the light of the country-specific context. First, the quotes of the two codebooks were translated into English. Second, both codebooks were evaluated for common themes and a common codebook was developed. Subsequently, an iterative secondary analysis process was used to assess similarities and differences between countries.

\subsection{Ethical consideration}

The protocol of the overarching SCUBY project has been approved by the Institutional Review Board of the Institute of Tropical Medicine (ref: 1323/19), the Ethical Committee University of Antwerp (ref: B300201940005, B300201941020), the Ethical Committee of the University Hospital (ref: 39884) and the National Ethics Committee of Slovenia (ref: 0120-219/2019/4).

\section{RESULTS}

Four themes were identified from the analysis: patientcentered care, teamwork, coordination of care and task delegation.

\subsection{Patient-centered care}

All experts emphasized the importance of patientcentered care. Nevertheless, interviewed patients with chronic diseases often experienced care as routine, i.e. care givers didn't consider the impact of the disease on their lives. The care providers stated that many patients did not understand their disease well enough and therefore could not self-manage their disease efficiently. 
We want comprehensive treatment (regular check-ups with health monitoring) and not just prescription of medications (Patient, code S-FSBC, Slovenia).

Patient associations are already well represented in both countries. However, stakeholders emphasized their fragmentation and insufficient implementation in the health system. Apart from that, they are usually insufficiently funded.

In Belgium, in light of the strictly medical approach in work processes, participants emphasized the importance of the affective aspect. Patients highlighted a need for guidance from healthcare professionals in coping with problems in their daily lives.

Sometimes it lacks the human aspect of care, the connection with people, although the nurse treats me somewhat differently; more like I am a real human being, without a label or a number (Patient, code B-VD12, Belgium).

Experts in Slovenia recognize the importance of moving healthcare from healthcare organizations to the patients' environment. Comprehensive care, including physiotherapy and especially occupational therapy, should be provided at home. Besides only nursing care, community nurses should also provide management of stable chronical diseases at patients' homes. However, such an approach requires more financial and human resources.

\subsection{Teamwork}

Participants from both countries emphasized the lack of teamwork and some professional groups as a major barrier to the scale-up of integrated care. Different professional groups treat the same patient; yet one professional group is not informed about the work of the other. GPs in particular, with their supervisory function, have problems delegating tasks to other professionals and multidisciplinary cooperation.

If we want a holistic approach, we lack other professionals who also deal with other health-related areas. However, cooperation between all those involved in the treatment of the patient is essential (Director of Community Health Center, code S-POS, Slovenia).

Recognized benefits of teamwork are the facilitation of patient-oriented care and greater cohesion between team members. On the other hand, some participants emphasized the concerns of teamwork with regard to the time burden on professionals.

The major risk of integrated care is that it requires so much consultation that one is constantly in meetings, so there is still little time for care on the long run (Health workers union, code B-IV7, Belgium).
To overcome the above mentioned barriers, respondents noted that it is important that all team members have the same and clear vision. The hierarchical structure should be dropped and the equality of all members should be ensured. Each member should know the boundaries of his or her work.

\subsection{Coordination of care}

Coordination of care was a key element for all respondents in the study. In both countries, patients report that GPs sometimes coordinate their care poorly. Some respondents indicate a need for a formal coordinator of care.

We see that GPs are overburdened, they become less accessible, but they are still given the central role, even though they are not in the middle of information when there is a complex situation. Decisions are not always made by persons who are best informed (Nurse, code $B-V D 2$, Belgium).

In both countries, the lack of communication between the different providers (especially between the primary and secondary/tertiary levels of healthcare) leads to suboptimal care and duplication of services; the latter also leads to a burden on the healthcare system and increasing costs.

Secondary level healthcare professionals should consult with the primary level before discharge of the patient from hospital to ensure appropriate patient follow (GP, code S-TFSA, Slovenia).

In the Belgian healthcare system, patients' freedom of choice of care providers was another factor identified as detrimental to the coordination of care. Also, the option for free access often leads to unnecessary and useless check-ups. As a result, patients are little guided and can get lost in the system; this also leads to high costs for the health system.

\subsection{Task delegation}

In both countries, stakeholders have emphasized the problem of an increasing burden on health workers, especially GPs. Both care givers and patients highlighted the importance of delegating tasks from GPs to nonphysicians.

In Belgium, although GPs are willing to entrust nurses in their practice, some health professionals share a certain concern about the implementation of nurses in primary care. The concerns about their adequate training, the acceptance of the new professional by patients, but mostly the current lack of funding by health insurance companies make providers reluctant to embrace this idea. However, patients seem to be receptive to implementation of a nurse or other disciplines in general practice. 
In Slovenia, the initial discomfort of patients with implementation of registered nurses quickly led to wide acceptance when patients realized their added value. Check-ups by nurses can be more tailored to the individual patient. GPs recognize them as a facilitating part of their work.

The advantage is that we have more time. In this way, we can explain the nature of the disease and the methods of treatment to the patient in more detail, which increases confidence in the treatment and improves adherence to treatment. In addition, regular education empowers the patient to live with the disease (Registered nurse, code S-TFSB, Slovenia).

In both countries, health professionals find that patients sometimes share more with a nurse than with a GP.

I'm kind of an 'intermediary' between a GP and a patient. That lowers some thresholds, I think. Some patients would rather share something personal with me than with the GP (Nurse, code B-AE5, Belgium).

\section{DISCUSSION}

The aim of this study was to investigate whether stakeholders in two different European countries, Slovenia and Belgium, reported different barriers to integrated chronic care. Our results show that this is the case, to a certain extent. The GP gatekeeper function and PHC organization in Slovenia probably facilitate the coordination of care, which is not the case in Belgium. The current funding and predominant doctor based practice in Belgium was recognized by the participants as an obstacle to implementation of a stronger delegation of tasks. In both health systems, true teamwork and patient-centered care were limited by hierarchy and a very heavily skewed medical approach. The differences in the identified facilitators and barriers in relation to the macro context of the country have also been recognized in other studies (6).

The barriers to patient-centered care identified in this study (care perceived as routine, decisions traditionally made by care providers, and lack of empowerment for self-management) seem somehow insensitive to significant organizational differences between PHCs in the two countries. The two main facilitators identified in our study to overcome the above-mentioned barriers were teamwork and coordination of care. All these findings are consistent with recently published research $(7,18,19)$. Other research also emphasizes the importance of developing training for health-care providers and the integration of information technology as important elements of patientcentered care $(7,19)$.
The results of this study underline the importance of teamwork in facilitating patient-centered care at the primary level. Due to the ever increasing possibilities and complexities of healthcare, the collaboration with different professional groups and their integration into healthcare services becomes ever more essential. However, our results suggest that communication between different healthcare providers remains insufficient, which is consistent with other research (20). Although nurses are slowly finding their way into PHC in Belgium, the majority of practices still consist of only a GP. In Slovenia, registered nurses and community nurses have been successfully introduced to PHC, and cooperation between them and GPs is often sufficient. However, there is still a strong hierarchy in both countries, as the GPs are the decision maker. On the other hand, there is a great lack of teamwork with other professionals at the primary level (clinical pharmacists, physiotherapists, psychologists, social workers, etc.). This study stresses the importance of professional integrity and the definition of roles and responsibilities of each professional group (i.e. task delegation) as a key element in facilitating teamwork, which is in line with other recent research (21). It also underlines the importance of team leadership, which should be the role of a GP, but in a partnership model. An important finding of our research was the concern of possible decreasing time spent on direct patient care due to increased time spent for coordination between different providers. This points to the need to develop tools allowing healthcare workers to collaborate efficiently, such as data-sharing and online meeting opportunities.

As this study shows, the coordination of care is another important aspect that deals with the increasing fragmentation of healthcare that we have been confronted with in recent years. In Belgium, patients can move between different providers (at primary and secondary level) without major restrictions. Such an approach possibly facilitates the accessibility of health services, but could also be a major barrier to coordinated care and can lead to patient getting lost in the complex health system. This has also been acknowledged by other recently published research (7). On the other hand, the capitation system in Slovenia is established at the primary level, so that patients cannot move freely between different GPs. Apart from this, the primary level represents a strong gatekeeper role. Patients do not have access to secondary and other primary level health services (e.g. physiotherapy, home care, laboratory and imaging diagnostics, etc.) by passing the GP. The above-mentioned characteristics of the Slovenian healthcare system may therefore facilitate the coordination of medical care, but not the coordination of other (non-medical) aspects of care (e.g. home care, financial matters, coaching, self-management, etc.), which was also highlighted in this study. This points to the need for a formal coordinator of care. Other studies 
also support the delegation of coordination from GP to other professionals $(7,20)$. However, there is no consensus yet on which professional group should represent this role. The care coordinator acts as a bridge between a patient and the healthcare system; therefore, he or she should have in-depth knowledge and skills to navigate the patient in the complex system. Some studies suggest that the coordinator should have medical knowledge and suggest that nurses should take on this role (22). Coordination of care at higher levels, which is not tailored to each patient individually, could also provide an answer to this question for a wider population. The general and disease-specific needs of patients should be identified and then some effective global interventions could be implemented. This could also reduce the burden on healthcare workers.

The increasing prevalence of NCDs and the growing complexity of healthcare in recent years with consequential increase of burden placed on healthcare workers (especially GPs) are identified as important barriers to improved patient-centered care. Other research has also linked this phenomenon to threatening the quality of care and lower patient satisfaction (23). As a result, many initiatives have been taken in recent years to reduce the burden on GPs while maintaining (or improving) the quality of care (e. g. introduction of registered nurses in Slovenia). The basic idea is to delegate some of the tasks of GPs to a non-physician. Experience shows that such interventions relieve the burden on GPs and improve the quality of care by accelerating the continuity of care. The results of some other studies are consistent with our findings - one study in primary diabetic care showed improved blood glucose control and higher patient satisfaction with the delegation of tasks from GPs to non-physicians (24). In Belgium, GPs show a willingness to delegate a number of tasks to nurses. As a result, despite the lack of financial support, nurses are increasingly employed in PHC practices $(17,25)$. It should be stressed that the fragmentation of healthcare is a possible by-product of the delegation of tasks between different professions. Therefore, a tendency to overcome this problem by supporting teamwork should be considered at all stages.

\subsection{Strengths and limitations of the study}

The strengths of the study relate to the covering stakeholders on all three (micro, meso and macro) levels; inclusion of all members of a team (on micro level) provides a comprehensive view of health workers at the topic. The selection of two countries with a different health system provides useful insight for other countries with similar health systems.

Apart primary data collected in this study, secondary data from recent research in Belgium were also included. We did not use the primary data; instead, the quotes from two published articles were used. The lack of purity which could potentially derive from the combination of primary and secondary data has been countered by the research team in the following ways: authors from all studies closely collaborating and meeting to discuss the reliability and validity of data; researchers being well embedded in the research context knowing the (lack of) changes in context between the secondary and primary studies; and triangulation with other studies examining the meso-level context by the same research team.

\section{CONCLUSIONS}

The integrated care package is recognized as an effective model because it supports all steps of the healthcare process and includes interactions within each level of healthcare as well as between levels. Therefore, it provides the basis for future scale-up interventions. This qualitative study with stakeholders at the micro, meso and macro levels enabled us to formulate some important concepts for the future healthcare of NCDs at the primary level. Patient-centered care should be accelerated by promotion of teamwork with task delegation to relief GPs. Furthermore, coordination of care should be endorsed, probably both by formalizing the coordinator of care (for individual patients) and by promoting coordination at higher levels (for the general population or specific diseases). We propose further research to determine the appropriate professional profile of care coordinators and how care could be coordinated in an intersectoral way at higher (organizational and political) levels. The study does not fully mention the healthcare outcomes.

\section{CONFLICTS OF INTEREST}

The authors declare that no conflict of interest exist.

\section{FUNDING}

This overarching SCUBY project is funded by the Horizon2020 Framework Programme of the European Union (grant no: 825432). The study sponsor and funders were not involved in the study design; collection, management, analysis, and interpretation of data; writing of the report; and the decision to submit the report for publication.

\section{ETHICAL APPROVAL}

The protocol of the overarching SCUBY project has been approved by the Institutional Review Board of the Institute of Tropical Medicine (ref: 1323/19), the Ethical Committee University of Antwerp (ref: B300201940005, B300201941020), the Ethical Committee of the University 
Hospital (ref: 39884) and the National Ethics Committee of Slovenia (ref: 0120-219/2019/4).

\section{REFERENCES}

1. Global status report on noncommunicable diseases. Accessed October 13th, 2020 at: https://apps.who.int/ iris/bitstream/handle/10665/44579/9789240686458_eng. pdf;jsessionid=7D0DB5BD0F4528406C6F19DC3F196A74? sequence $=1$.

2. Dobrow M. Caring for people with chronic conditions: a health system perspective. New York: Mc Graw Hill, 2009.

3. Atun R, De Jongh T, Secci F, Ohiri K, Adeyi O. A systematic review of the evidence on integration of targeted health interventions into health systems. Heal Policy Plan. 2010;25(1):1-14. doi: 10.5334/ ijic.298.

4. Stone MA, Charpentier G, Doggen K, Kuss O, Lindblad U, Kellner C, et al. Quality of care of people with type 2 diabetes in eight European countries: findings from the guideline adherence to enhance care (GUIDANCE) study. Diabetes Care. 2013;36(9):2628-38. doi: 10.2337/ dc12-1759.

5. Kringos DS, Boerma WG, Bourgueil Y, Cartier T, Hasvold T, Hutchinson A, et al. The european primary care monitor: Structure, process and outcome indicators. BMC Fam Pr. 2010;11(1):81. doi: 10.1186/14712296-11-81.

6. Threapleton DE, Chung RY, Wong SYS, Wong E, Chau P, Woo J, et al. Integrated care for older populations and its implementation facilitators and barriers: a rapid scoping review. Int J Qual Heal Care. 2017;29(3):327-34. doi: 10.1093/intqhc/mzx041.

7. Monaco A, Palmer K, Marengoni A, Maggi S, Hassan TA, Donde S. Integrated care for the management of ageing-related noncommunicable diseases: current gaps and future directions. Aging Clin Exp Res. 2020;32(7):1353-8. doi: 10.1007/s40520-020-01533-z.

8. Current health expenditure per capita. Accessed October 14th, 2020 at: https://data.worldbank.org/indicator/SH.XPD.CHEX.PP.CD.

9. Current health expenditure. Accessed October 14th, 2020 at: https:// data.worldbank.org/indicator/SH.XPD.CHEX.GD.ZS.

10. Albreht T, Pribakovic Brinovec R, Josar D, Poldrugovac M, Kostnapfel T, Zaletel M, et al. Slovenia: Health system review. Heal Syst Transit. 2016;18(3):1-207.

11. Klemenc-Ketis Z, Švab I, Stepanović A, Poplas Susič A. Transition from a traditional to a comprehensive quality assurance system in Slovenian family medicine practices. Int J Qual Heal Care. 2019;31(4):319-22. doi: 10.1093/intqhe/mzy157.

12. Johansen AS, Vracko P, West R. The evolution of community-based primary health care, Slovenia. Bull World Heal Organ. 2020;98(5):3539. doi: 10.2471/BLT.19.239616.

13. Gerkens S, Merkur S. Belgium: Health system review. Heal Syst Transit. 2010;12(5).

14. van Olmen J, Menon S, Poplas Susič A, Ir P, Klipstein-Grobusch $K$, Wouters E, et al. Scale-up integrated care for diabetes and hypertension in Cambodia, Slovenia and Belgium (SCUBY): a study design for a quasi-experimental multiple case study. Glob Health Action. 2020;13(1). doi: 10.1080/16549716.2020.1824382.

15. Gilson L. Health policy and systems research: a methodology reader. Geneva: WHO, 2013.

16. Van Durme T, Macq J, Anthierens S, Symons L, Schmitz O, Paulus D, et al. Stakeholders' perception on the organization of chronic care: a SWOT analysis to draft avenues for health care reforms. BMC Heal Serv Res. 2014;14(1). doi: 10.1186/1472-6963-14-179.

17. Aerts N, Van Bogaert P, Bastiaens H, Peremans L. Integration of nurses in general practice: a thematic synthesis of the perspectives of general practitioners, practice nurses and patients living with chronic illness. J Clin Nurs. 2020;29(1-2):251-64. doi: 10.1111/jocn.15092.

18. Goodwin C. Person-centered care: a definition and essential elements. J Am Geriatr Soc. 2016;64(1):15-8. doi: 10.1111/jgs.13866.
19. Poitras ME, Maltais ME, Bestard-Denommé L, Stewart M, Fortin M. What are the effective elements in patient-centered and multimorbidity care? A scoping review. BMC Heal Serv Res. 2018;18(1). doi: 10.1186/ s12913-018-3213-8.

20. Stumm J, Thierbach C, Peter L, Schnitzer S, Dini L, Heintze C, et al. Coordination of care for multimorbid patients from the perspective of general practitioners - a qualitative study. BMC Fam Pr. 2019;20(1). doi: 10.1186/s12875-019-1048-y.

21. Levesque JF, Harris MF, Scott C, Crabtree B, Miller W, Halma LM, et al. Dimensions and intensity of inter-professional teamwork in primary care: evidence from five international jurisdictions. Fam Pr. 2018;35(3):285-94. doi: 10.1093/fampra/cm×103.

22. Izumi S, Barfield PA, Basin B, Mood L, Neunzert C, Tadesse R, et al. Care coordination: identifying and connecting the most appropriate care to the patients. Res Nurs Heal. 2018;41(1):49-56. doi: 10.1002/ nur.21843.

23. Panagioti M, Geraghty K, Johnson J, Zhou A, Panagopoulou E, ChewGraham C, et al. Association between physician burnout and patient safety, professionalism, and patient satisfaction: a systematic review and meta-analysis. JAMA Intern Med. 2018;178(10):1317-30. doi: 10.1001/jamainternmed.2018.3713.

24. Mirhoseiny S, Geelvink T, Martin S, Vollmar HC, Stock S, Redaelli M. Does task delegation to non-physician health professionals improve quality of diabetes care? Results of a scoping review. PLoS One. 2019;14(10). doi: 10.1371/journal.pone.0223159.

25. Matthys E, Remmen R, Van Bogaert P. Practice nurse support and task suitability in a general practice: a cross-sectional survey in Belgium. J Interprof Care. 2019;33(6):661-9. doi: 10.1080/13561820.2019.1569602. 
Appendix 1. Selection of participants.

\begin{tabular}{|c|c|c|}
\hline Participants level & Slovenia & Belgium \\
\hline \multirow[t]{6}{*}{ Micro (FGs) } & FG Patients - Ljubljana (6 focus groups) & \multirow[t]{6}{*}{ Secondary data } \\
\hline & FG Patients - Ravne na Koroškem & \\
\hline & FG Health Professionals - Ljubljana (5 focus groups) & \\
\hline & FG Health Professionals - Lendava & \\
\hline & FG Health Professionals - Gornja Radgona & \\
\hline & FG Health Professionals - Ravne na Koroškem & \\
\hline \multirow[t]{13}{*}{ Meso (interviews) } & Community Health Centre Ljubljana (3 interviews) & Medical Association of GPs (Domus Medica, DM) \\
\hline & Community Health Centre Postojna & Belgian Association of Doctors Syndicates (BVAS) \\
\hline & \multirow{2}{*}{$\begin{array}{l}\text { Institution for informal home care } \\
\text { (Zavod za oskrbo na domu) }\end{array}$} & \multirow{4}{*}{ General Pharmaceutical Association (APB) } \\
\hline & & \\
\hline & Municipality of Ljubljana (2 interviews) & \\
\hline & $\begin{array}{l}\text { Associations of patients with chronic diseases } \\
\text { (Društvo Za Srce) ( } 2 \text { interviews) }\end{array}$ & \\
\hline & Retirement home (Dom starejših občanov Tabor) & Association of Diabetes Nurses \\
\hline & \multirow[t]{6}{*}{$\begin{array}{l}\text { Associations of patients with chronic } \\
\text { diseases (Društvo diabetikov) }\end{array}$} & $\begin{array}{l}\text { Flemish Association of } \\
\text { Independent Nurses (VBZV) }\end{array}$ \\
\hline & & Network of Homecare Nurses (Zorggezind) \\
\hline & & Association of Home Nursing (WGK) \\
\hline & & Flemish Patient Platform (VPP) \\
\hline & & Flemish Diabetes Association (Diabetes liga) \\
\hline & & $\begin{array}{l}\text { First line zone ( } 3 \text { zones: Antwerp, } \\
\text { Ghent, Kempenland) }\end{array}$ \\
\hline \multirow[t]{10}{*}{ Macro (interviews) } & National Institute for Public Health (2 interviews) & Federal Public Service of Health (FOD) \\
\hline & National Institute for Health Insurance & Flemish Cabinet \\
\hline & Ministry of Health (2 interviews) & \multirow[t]{2}{*}{$\begin{array}{l}\text { Association of Flemish Cities } \\
\text { and Municipalities (VVSG) }\end{array}$} \\
\hline & Chamber of Pharmacies & \\
\hline & Health Council at Ministry of Health & \multirow{2}{*}{$\begin{array}{l}\text { National Institute of Health \& Disability } \\
\text { Insurance (NIHDI) ( } 3 \text { interviews) }\end{array}$} \\
\hline & $\begin{array}{l}\text { Chamber of nurses, midwives and } \\
\text { healthcare assistants of Slovenia }\end{array}$ & \\
\hline & $\begin{array}{l}\text { Medical University of Ljubljana, Department } \\
\text { of Family Medicine ( } 3 \text { interviews) }\end{array}$ & $\begin{array}{l}\text { Christian Health Fund (CM) } \\
\text { Joint College of Sickness Funds (NIC) }\end{array}$ \\
\hline & \multirow[t]{3}{*}{ Medical Chamber } & Socialist Sickness Fund \\
\hline & & Federal Knowledge Centre for Healthcare (KCE) \\
\hline & & Academia/Medical universities ( 2 interviews) \\
\hline
\end{tabular}


Appendix 2. Focus groups and interview guide.

Introduction of the researcher(s)
- Thank
- Name \& function of researcher
Explain purpose and the intent of the FG/interview:
- Aim of FG/interview: gaining insight into opinions and perceptions of patients, healthcare
teams and community actors in relation to integrated care, its barriers and facilitators
- Duration of FG/interview (max 90 min)
- Ensure confidentiality
Informed consent
- Ask (to sign) the informed consent and permission to record the FG/interview
1. How do you see the current implementation of integrated chronic disease
care in your country? What favors and what hinders it?
2. What do you think is currently an obstacle to tailor healthcare more to the
individual person? What could facilitate such an approach?
3. How do you see collaboration between the patient and health professionals; and between
different professionals within and outside the team? What are the barriers and facilitators?
4. How well coordinated is healthcare currently? What hinders and what facilitates the coordination of care?
The questions were followed by additional sub-questions, that emerged from the responses of the current
interviewee or focus group participants as well as aspects already identified by previous interviewees
or focus group participants. Such an approach allowed us to gain more in-depth information.

Concluding remarks

Additional comments

- Do you have any additional remarks?

Thank

- Thank you for your time. 